\title{
HISTOLOGICAL AND HISTOCHEMICAL STUDIES ON THE EPIDIDYMIS OF THE TUPAIIDAE (TREE SHREWS)
}

\author{
Fayed, M. H; Mona A. Ali. and Atif H. \\ Department of Anatomy and Histology, Faculty of Veterinary Medicine \\ Tanta University, Kafr EL- Sheikh.
}

\begin{abstract}
The samples of epididymal duct were collected from three monkeys of Tupaiidae species.Sections of 4um thickness were prepared for histological and histochemical studies. The histological studies showed that the epithelium lined the head region consisted of single layer of high columnar ciliated cells, changed gradually to pseudostratified columnar ciliated in the body region and into low columnar or cuboidal in the tail region. There were large light stained cells with two different shapes throughout the epithelium. The histochemical studies showed periodic acid Schiff $(P A S)+v e$ reaction in the apical part of the principal cells with their cilia in the head region, where in the body region the PAS+ve reaction was condensed in the free border of the epithelium; and in the tail region the reaction was condensed in the free surface and the cytoplasm beneath it. The Alcian blue at $\mathrm{pH} 2.5$ (Ab 2.5) +ve reaction was condensed in the free surface with their cilia in the all regions. The light cells showed PAS and $A b 2.5+v e$ granules especially in the tail region.In lectin stained tissue, the stained area was confined to the cilia,free surface, and the cytoplasm beneath it.
\end{abstract}

\section{INTRODUCTION}

Non human primates present a unique animal model for human disease because of their phylogenetic closeness to human,their convenient size, rather their omnivorous natural diet and their ability to stay healthy in captivity. On the other hand, the glycoconjugats have been recorded to play an important role for the physiological functions of the organs(Arya et.al.1985). The use of conventional histochemical staining as PAS or Ab 2.5 permitted to distinguish containing carbohydrates macromolecules 
and supplied information on different types of glycoconjugats. Certainly, the introduction in the glycohistochemistry of highly specific markers as lectins allows to fine characterization of glycoconjugats components (Scocco, 2002).

The aim of this study is to investigate the histochemical structure and the distributions of the sugar residues and their suggested biology in the monkey's epididymis using two lectins as probe and FITC as visulant.

\section{MATERIALS AND METHODS}

The samples for this study were collected from three animals of Tupaiidae obtained from Department of Anatomy, United graduated School of Veterinary Medicine, Yamaguchi University, Yoshida16771,Yamag-uchi shi 755, Japan. All investigations were completed in the department of anatomy and histology, faculty of veterinary medicine, Kafr El-Sheikh, Tanta University, Egypt.

The monkeys were scarified under deep anesthesia with an intravenous injection of pentobarbital sodium $(50 \mathrm{mg} / \mathrm{kg})$. The epididymis was fixed in 4\%paraformaldehyd in phosphate buffer saline (PBS),for 72 hours and thoroughly rinsed in the same buffer. Sections of 4um thickness were deparafinized in xylene and stained with Gill's hematoxyline (Gill's et. al., 1974) and eosin (H\&E), histochemical staining PAS, Ab at $\mathrm{pH}$ 2.5,peanut agglutinin (PNA) and horse Doichos biflorus agglutinin(DBA)as lectins of choice \}as shown in table (1) :

Table (1): Carbohydrate binding specificity of lectins used in this study.

\begin{tabular}{|c|c|c|c|c|c|c|}
\hline $\begin{array}{l}\text { Taxonomi } \\
\text { c name }\end{array}$ & $\begin{array}{c}\text { abbrevi } \\
\text { ations }\end{array}$ & $\begin{array}{l}\text { Common } \\
\text { name }\end{array}$ & $\begin{array}{l}\text { Label } \\
\text { used }\end{array}$ & $\begin{array}{c}\text { Concentra } \\
\text { tion used } \\
\text { ug/ml }\end{array}$ & $\begin{array}{c}\text { Major sugar } \\
\text { specifications }\end{array}$ & $\begin{array}{c}\text { Sugar } \\
\text { binding } \\
\text { inhibit } \\
\text { or }\end{array}$ \\
\hline $\begin{array}{l}\text { Archis } \\
\text { hypogaea }\end{array}$ & $\overline{P \text { PNA }}$ & Peanut & FITC & 100 & $\begin{array}{l}\text { Gal-B-(1- } \\
\text { 3)GalNAc }\end{array}$ & Lactose \\
\hline $\begin{array}{l}\text { Dolichos } \\
\text { biflorus }\end{array}$ & $\overline{\text { DBA }}$ & Horse germ & FITC & 100 & $\alpha$-D-GalNAc & - \\
\hline
\end{tabular}

$\mathrm{Gal}=$ Galactose $;$ GalNA $\mathrm{c}=\mathrm{N}$-acetylgalactosamine; FITC $=$ fluorescent isothiocyanate

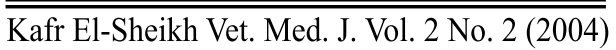


The processing and staining procedure with the various lectins (table1) was similar to that described by Bancroft and Stevens, (1996) and Rhodes and Milton, (1998).

\section{RESULTS}

\section{1-Histological studies:}

The tissue stained with H\&E showed that the epithelium lining of the head of the monkey's epididymis consisted of simple high columnar ciliated darkly stained cells with long cilia. The lumen of the epididymal ducts was regular, circular or ovoid and nearly empty of spermatozoa (fig.1).

In the body region of the epididymis, the columnar epithelium changed gradually to pseudostratified columnar ciliated cells. The cilia were shorter than those in the head region(fig.2).Few irregular large cells with pale cytoplasm and spherical centrally located nuclei were present among the epithelium(light cell)(fig.3). The lumen of the epididymal ducts were relatively filled with spermatozoa.

In the tail segment the epithelium was sharply decreased in its height and formed of low columnar or cuboidal cells, their cilia were sharply decreased in their heights (fig. 4). The light cells were increased in their amount and differ in their shapes about those in the body region, their were cuboidal large cell with vacuolated cytoplasm and oval basally located nucleus (fig. 5). The lumen of the epididymal ducts were compacted with spermatozoa.

\section{2-Histochemical studies:}

\section{Periodic acid Schiff's reaction (PAS):}

In the head of monkey's epididymis, the apical half of the principle columnar ciliated cells with their cilia exhibited PAS +ve reaction(fig.6). In the body segment, the PAS reaction was condensed in the free border of the epithelium with their cilia (fig. 7). In the tail segment, the PAS reaction was very deep and condensed in the free border of cells and in the cytoplasm of them (fig. 8). The light cells in all segments contained PAS+ve granules but these granules increased in the light cells of the tail region (fig. 9). 


\section{Alcian blue at pH 2.5 (Ab 2.5):}

In all segments, the $\mathrm{Ab}+\mathrm{ve}$ reaction was condensed in the free border of the principal cells with their cilia (fig. 10). The light cells especially in the tail segment showed $\mathrm{Ab}+\mathrm{ve}$ reaction (fig. 11).

\section{Lectin histochemistry:}

\section{A- Peanut agglutinin (PNA):}

The supranuclear and apical cytoplasm of the epithelial cells of the head region exhibited apparent weak PNA +ve reaction (fig. 12); where in the body region the PNA +ve reaction was obtained throughout the cytoplasm with the apical border and cilia (fig.13). In the tail region the +ve reaction was more distinct throughout the cytoplasm than that in the body region (fig.14).

\section{B-Dolichos biflorus (DBA):}

The positive reaction was distinct in the apical cytoplasm, apical border and the cilia in the head and the tail regions (fig. 15). The positive reaction in this procedure appeared as yellowish green fluorochrome.

\section{DISCUSSION}

In this study a simple layer of high columnar ciliated darkly stained cells lined of the head region of the monkey's epididymis. These columnar cells were changed gradually in the body region to pseudostratified columnar ciliated cells, which were sharply decreased in their heights in the tail region and changed into low columnar or cuboidal cells. Another type of cells was observed in the body and tail regions, these cells were lightly stained and differed in their number and shape from body to tail regions. Tingari (1989) and Basset Aly et al (1995) observed that the epithelial lining of epididymal ducts of bull contained principal,basal and dark cells in all regions in addition to the apical cells. While Abdou et al (1985) claimed that the bull epididymal ducts contained clear cells.

The lumen of the epididymal duct in head region in our study was regular, circular or ovoid, while Safuat (2000) and Tuskise et al (1989) showed star shaped appearance of the lumen of this region. 
In the present study, the initial segment of the head epididymal region showed PAS+ve reaction in the apical half of the principal columnar ciliated cells with their cilia, where in the body segment the PAS+ve reaction was condensed in the free border of the epithelium. Tsukis et al (1989) noted that the Golgi and the apical areas of the principal cells exhibited vivid reaction in the proximal segment of the goat epididymis. He added that the presence of well-developed Golgi complex in the principal cells of the epididymal duct especially in the part of the head supported the principal cells ability to synthesis and secret protein/glycoprotein in this region. This coincide with the observation on regional differences in the intra-luminal sperm concentration, that the body and tail parts were not secretory rather than absorptive, (Amann et al, 1982 and Goyal, 1989).

The light cells in all segment especially in the tail segment in our study contained strongly PAS+ve granules. Also, they showed Ab+ve reaction.So,these cells considered as seromucoid secreting cells according to Scocco et al(2002)who considered that the sites showed PAS+ve reaction due to presence of glycoaminoglycans and also showed basophilia due to presence of acid glycoprotein as seromucos. They added that these glycoconjugats could evolve or modify themselves following changes of physiological and environmental condition. There is also a specific defensive role to the mucosa related to glycoconjugates (Nieuw-Amerongen et al, 1995).

The present study revealed that the $\mathrm{Ab}$ reaction condensed in the luminal surface of the principal cells with their cilia in all region of monkey's epididymis. In addition, the light cells gave Ab+ve reaction. Pearse (1968) detected that the Ab 2.5 stained both carboxylated and sulphated groups in glycoconjugates. 
In lectin staining tissue in this work the stained area was confined to the cilia,free surface, and the cytoplasm beneath it.Watanabe et al(1981) suggested that the staining of epithelium due to mucin or its precursor. Also, the affinity for DBA or PNA conjugates identifies the many Olinked oligosaccharides containing GalNAc. In addition, the GalNAcreactive lectins have demonstrated in a wide range of epithelial cells performing secretory and transport functions (Spicer et al; 1983, Spicer et al; 1987 and Schulte et al; 1990).

In Conclusion: The lining epithelium of the ductus epididymis of monkey formed of two types of cells, principal darkly stained cells and large lightly stained cells. The epithelium found to contained acidic and neutral glycoconjugates with various saccharide as Galactose and $\alpha \mathrm{N}$ acetyelgalactosamine.

\section{FIGURES}

Fig. (1): Paraffin section in the head region showing; the simple columnar epithelium lined the epididymal duct (solid arrowheads). (H\&E stain; X: 100).

Fig. (2): Paraffin section in the body region showing pseudostratified epithelium lined the epididymal duct (solid arrowheads). (H\&E stain; X: 100).

Fig. (3): Higher magnification of figure 2 showing the shape of light cell (open arrowhead). (X: 1000).

Fig. (4): Paraffin section in the tail region showing the cuboidal epithelium lined the epididymal duct (solid arrowheads) the light cell (open arrowheads) (H\&E stain; X: 100). 
Fig. (5): Higher magnification of figure 4 showing the shape of light cell (X 1000).

Fig. (6): Paraffin section in the head region showing PAS +ve reaction in the apical surface of the principal cells (solid arrowheads). (PAS tech. X: 400).

Fig. (7): Paraffin section in the body region showing PAS +ve reaction in the free border of the epithelium (solid arrowheads). (PAS tech. $\mathrm{X}:$ 400).

Fig. (8): Paraffin section in the tail region showing PAS + ve reaction in the free border of cells (solid arrowheads) (PAS tech. X: 100).

Fig. (9): Paraffin section in the tail region showing PAS +ve granules in the light cells (open arrowheads). (PAS-H tech. X: 400).

Fig.(10)\&(11): Paraffin sections in the tail region showing Ab+ve reaction in the free border of epithelium (solid arrowheads)and in the light cell (open arrowhead). (Ab stains; X: 10; $100 \& 11 ; 400$ ).

Fig.(12):Paraffin section in the head region showing the PNA+ve reaction (arrows). (FITC-PNA stain, X 100).

Fig. (13): Paraffin section in the body region showing the PNA+ve reaction (arrows). (FITC-PNA stain, X 100).

Fig. (14):Paraffin sections in the tail region showing the PNA+ve reaction (arrows). (FITC-PNA stain, X 100).

Fig. (15): Paraffin section in the head region showing the DBA+ve reaction (arrows). (FITC-PNA stain, X 100). 
Fayed, M. H; Mona A. A. \& Atif H.

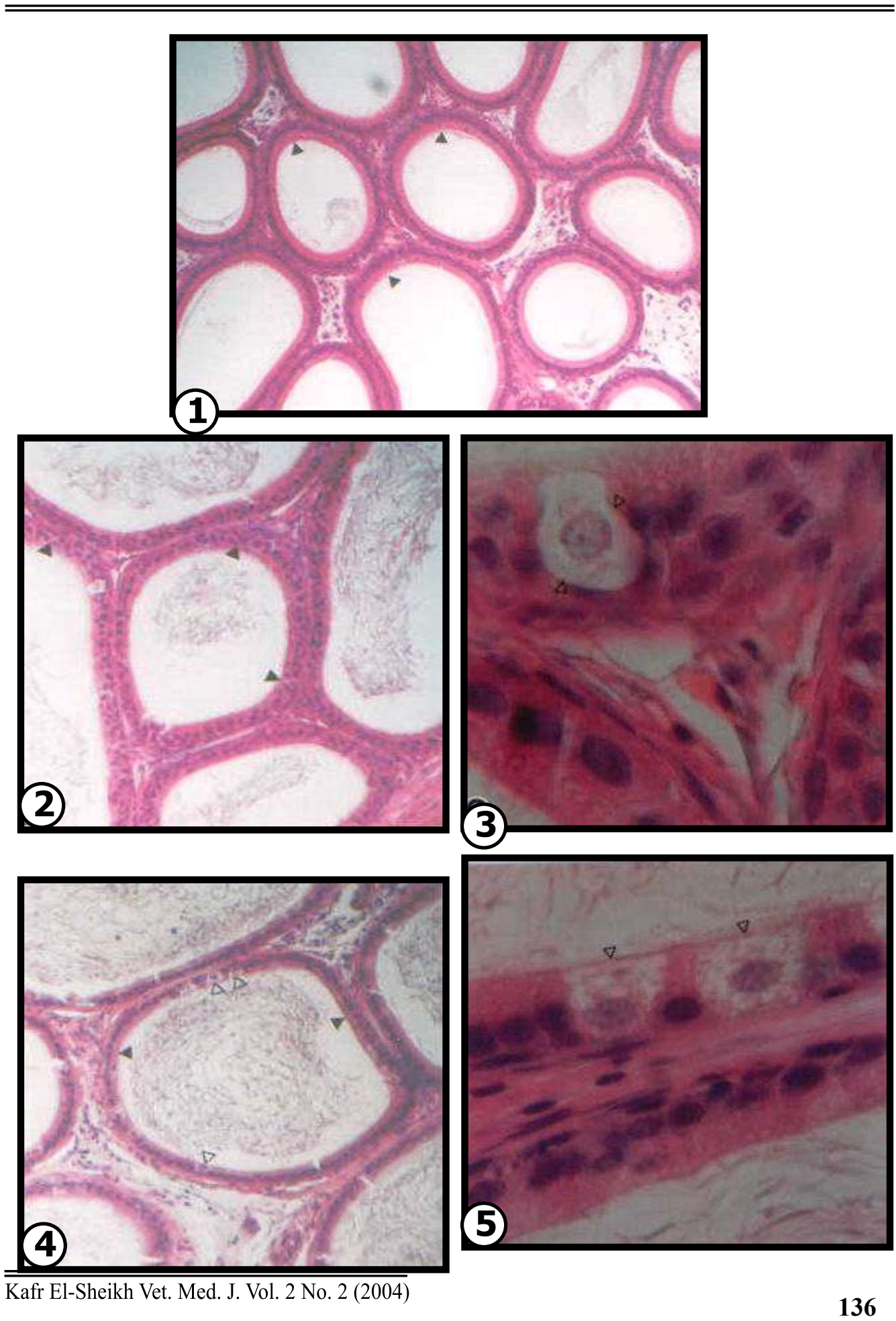


Histological And Histochemical Studies On ...
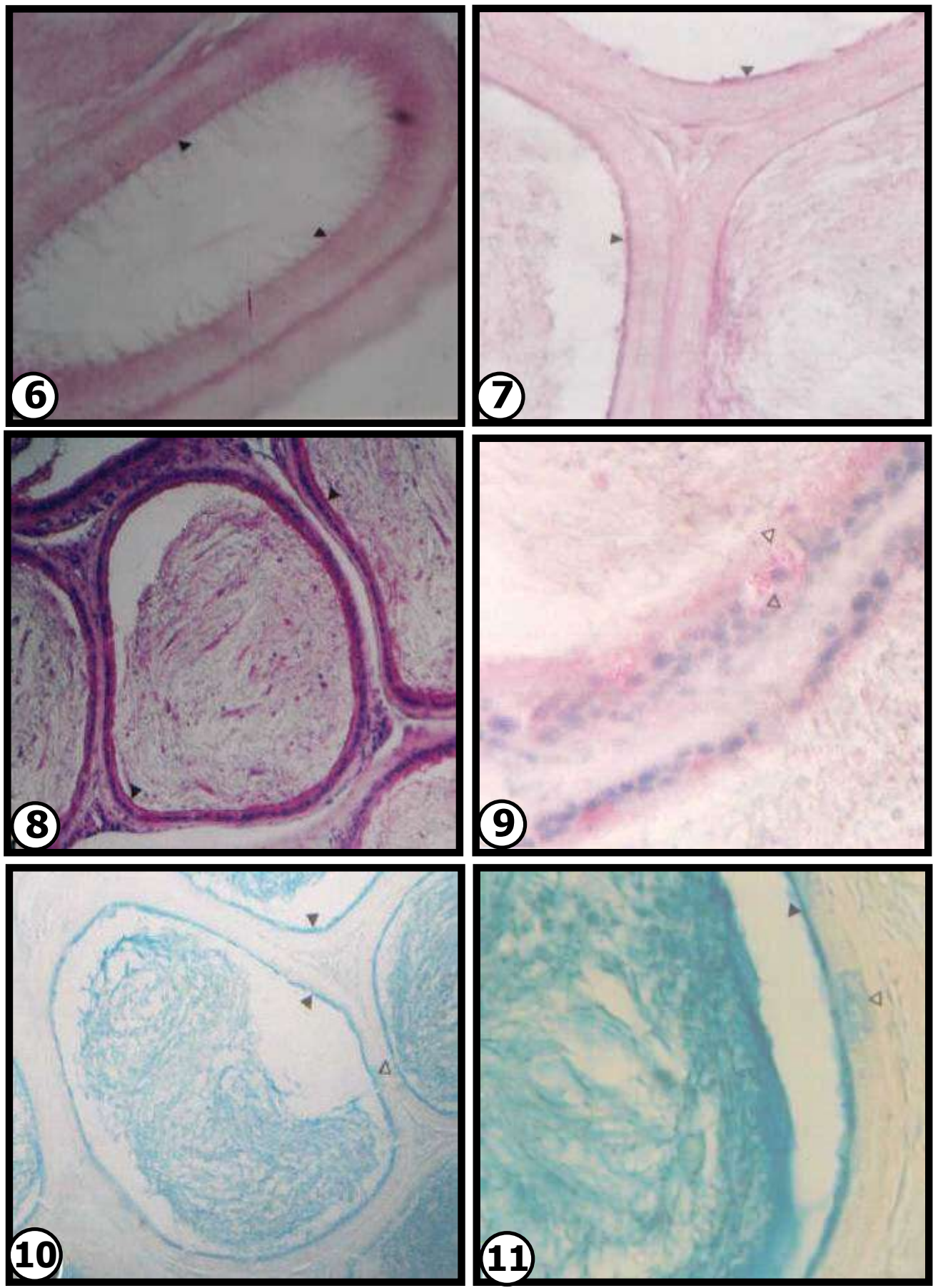

$\overline{\text { Kafr El-Sheikh Vet. Med. J. Vol. } 2 \text { No. } 2 \text { (2004) }}$ 
Fayed, M. H; Mona A. A. \& Atif H.
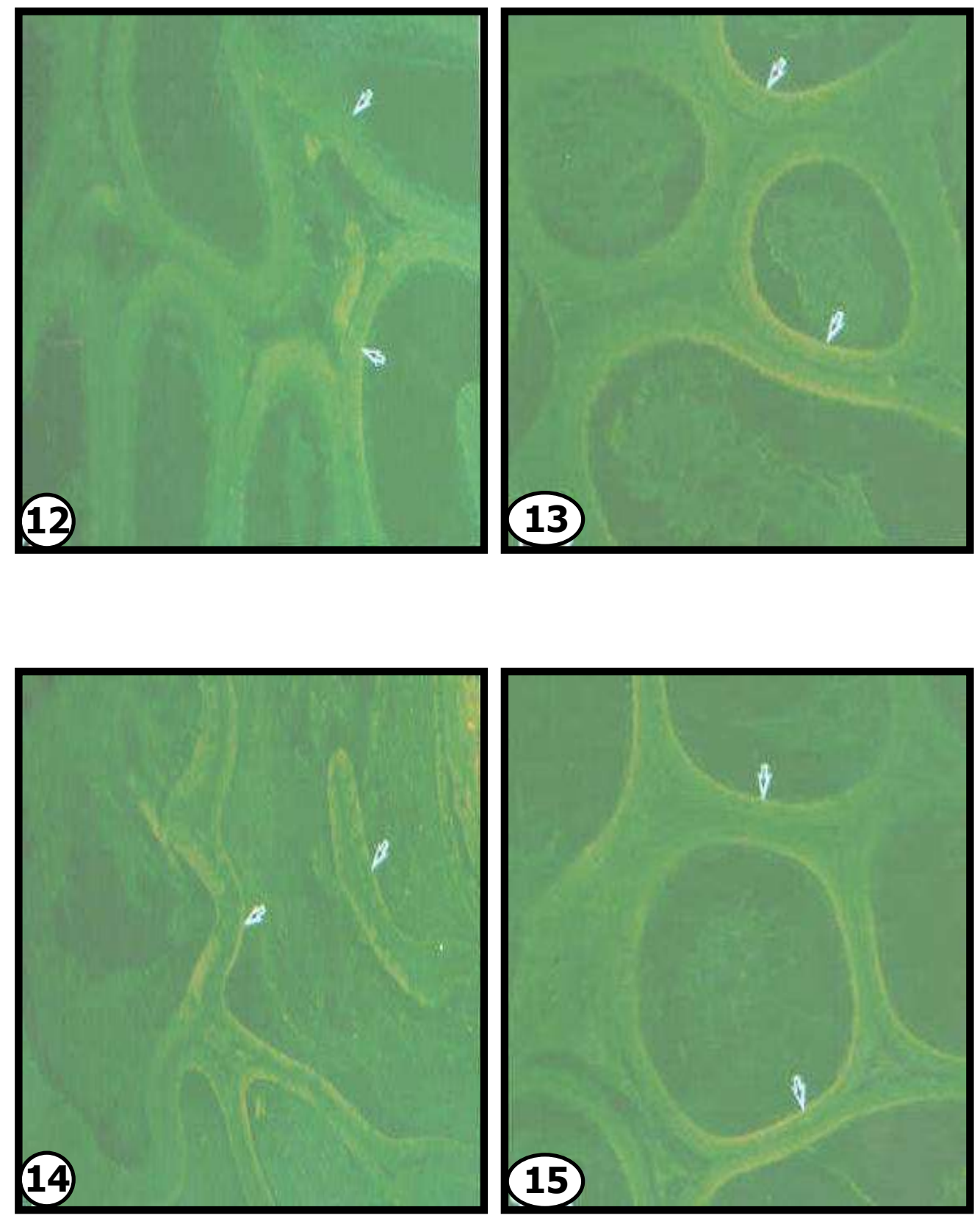

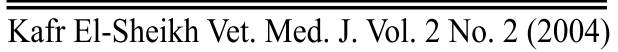




\section{REFERENCES}

- Abdou, M. S.;Moussa,M. H. G.;Ragab, R. S. and El_Menoufy, A. A (1985): On the regional histology and histochemistry of the ductus epididymis in the buffalo.Zbl Vet.Med.C Anat.Embryol.(14): 226-235.

- Amann. R. P.;Hay, S. R. and Hammersted,R. h.(1982):Yield characteristic, motility and cAMP of sperm isolated from seven regions of ram epididymis. Biol. Reprod. 27: 723-733.

- Arya, M.; Vanha-Perttula,T. (1985): Lectin-binding pattern of bull testis and epididymis. J. Androl. 6: 230-242.

- Banroft, J. D. and Stevens, A. (1990): Theory and Practice of Histological Techniques. Churchill Livingstone, Einberg, London.

- Basset,A.and Khidir,I.(1986): The ultrastructure of the normal prostate acini of the camel (Camellus dromedaries). Zagazig Vet. J. 13: 79-89.

- Gill,G.;Frost,J.and Miller,K(1974): A new formula for half oxidized Haematoxylin solutions that neither over stain nor require differentiation. Acta Cytol. 18; 300-311.

- Goyal, H. O. (1989): Application of regional differences in sperm concentration in predicting absorptive or secretory function of the epididymis in the goat. Anat. Histol. Embryol. (Abstract).

- Nieuw-Amerongen,A.V.;Bolscher,J.G.M.; Veerman, E.C.I. (1995): Salivary mucins: [protect relation to their diversity. Glycobiology 5, 733-740.

- Rhodes, J. and Milton, J. (1998): Lectin methods and protocols. $1^{\text {st }}$ ED. Humana Press. Totowa, New Jersey.

- Pearse,A. G. E.(1968): Histochemistry theoretical and applied.(ed. Churchill, A. \&J.) $3^{\text {rd }}$ 659-660 London.

- Safwat,E.M.(2000):Morphological studies on the testis and epididymis of water buffalo (Bos bubalis).A Thesis sub. Zagazig Univ. Vet. Med.

- Schulte, B. A.; Haeley, R. A.; Spicer, S. S. (1990): Carbohydrate histochemistry. In Gil J, ed. Models of lung disease: microscopy and structural methods. Lung biology in health and disease series. New York, Marcel Dekker. 147. 
- Scocco,P.;Fgioli O.;Ceccarelli,P.and Pedini V.,(2002): From conventional to modern histochemistry: way for the fine characterization of secretion glycoconjugates. Embryol. 107; 3: 43-54.

- Spicer S. S.,Erlandsen SL., Wilson AC.,Hammer MF.Hennigar RA., Schulte BA. (1987): Genetic differences in the histochemical defined structure of oligosaccharides in mice.

- Spicer,S.S.,Schulte,B.A., Thompoulos, G. N., Parmley,R.;Takagi, M. (1983): Cytochemistry of complex carbohydrates by light and electron microscopy : Available methods and their application.In Wanger BM., Fleischmajer R.,Kaufman N.,eds.Connective tissue disease.Baltimore, Williams\&Wilkins; 163.

- Tingari, M. D. (1989): The fine structure of the epithelial lining of the epididymis of the camel (Camellus dromedaries)with special reference to regional differences. J. Ant. (165): 201-214.

- Tsukis,A,Fujimori,O. and Yamada,K. (1989): Glycoconjugats Histochemistry of the epididymis in the goat.Proceedings of the Kagoshima International Symposium of Glycoconjugates in Medicine. 36-40.

- Watanabe M., Muramatsu T., Shirane H., Ugai K. (1981): Discrete distribution of binding sites for Dolicbos biflorus agglutinin (DBA) and for Peanut agglutinin (PNA) in mouse organ tissue.

$$
\begin{aligned}
& \text { در اسات هستولوحية و هستوكيميائية على بربخ القرود متسلقة الأشجار } \\
& \text { مسعول حسن فايِ و منى عبل الفتاح على }
\end{aligned}
$$

يتكون الغثـاء الطلائى المبطن لقناة البربخ فـى القرود من طبقة واحدة من الخلايـا العماديـة المهدبة فى منطقة الراس، تتحول تدريجيا الى خلايا شبة عمادية مهدبة فى منطقة الجسم ثم الى خلى فلايا

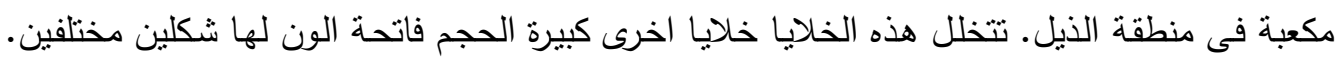

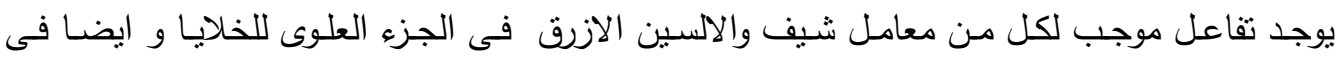
الاهداب. يوجد ايضا تفاعل موجب لكل من معامل شيف والالسين الازرق فى الخلايا اتلفاتحة. يوجد تفاعل موجب للكتين فى الاهداب والسطح الخارجى للخلايا والسيتوبلازم بين الخلايا. 